\title{
Emerging Communication Technology and Examination Malpractices in Nigerian Education Sector
}

\author{
doi:10.3991/ijet.v5i4.1455 \\ Olufemi Sunday Adeoye \\ University of Uyo, Nigeria
}

\begin{abstract}
The breakthrough in communication technology, especially that of GSM phones, in Nigeria is one of the best things that has happened to the nation in terms of its technological advancement. In Nigeria, GSM means Telecom Explosion. The GSM revolution began in August 2001 and changed the face of Information and Communications Technology in Nigeria. It is much easier to reach anybody that you have his / her number, whether they are in the village or in their closet unless in a place where there is no network of the service provider. As revolutionary as GSM may seem to be, its negative effect on our educational sector is of great concern. The ongoing war against examination malpractice is yet to take its toll on perpetrators as they have devised a new method to continue their game through the cell phone technology. Described as e-cheating, the cell phone technology is providing students a smart way to beat the best effort of stakeholders to stamp out the menace. This paper examines GSM technology, the various ways in which cell phones are employed to cheat and suggestions on how to stop e-cheating through cell phones.
\end{abstract}

Index Terms-emerging communication technology, examination malpractice, e-cheating, GSM services.

\section{INTRODUCTION}

The importance of communication can not be overemphasized. It is one of the vital tools on which the human race exists. Technological advancement in the western world has impacted the rest of the world and it is now a global village. The breakthrough in communication technology which has hit Africa has ushered her into the giant economic field. The rest of the world can easily reach some of the developing countries now; they are becoming more accessible compared to a couple of years ago. GSM is now connecting villages to cities, cities to countries, countries to countries and continent to continent. GSM has indeed given Africa a voice. GSM has been of great help in communication. We can reach people and connect them. You cannot overemphasize the feeling of talking to your parent and friends on the phone. You can even be part of occasion back home; all you do is call on the day of wedding or special ceremony and speak to as many people as possible. We can track event and people and stay connected unlike before. GSM has also helped to reduce the pressure on us to come home or travel long distance thus reducing accident on our roads, we are well informed now of what is happening and communication is more frequent and also they can reach us or send text messages.

\section{BACKGROUND TO THE STUDY}

The Global system for mobile communication (GSM) is an open, digital cellular technology used for transmitting mobile voice and data services. Mobile phones are looked upon as a modern invention. However, their origin could be traced back to the invention of telephone way back by Graham Bell in 1870s and success in the capture of radio message. Since those events, these basic technologies have merged and shaped themselves together as mobile phone.

Summing up the history of mobile phones we can say that the telephone were the beginning of the whole system. Radio charted the progress of radio communications. Both technologies came together to bring Radio Telephones. Then came cellular which marked the development of the popular cellular phone systems. Another step was digital which led to the emergence of a digital standard, GSM. Satellites helped mobile phones emerge as the preferred medium of communication at the global level.

August 2001 was a pivotal date in the history of Nigeria. That was when the first Global System for Mobile (GSM) Communications call was made under a democratic government (specifically, Chief Olusegun Obasanjo). This event heralded the dawn of a new era "the era of GSM technology, which has completely changed the face of Information and Communications Technology in Nigeria [10]. Since the GSM launch, mobile telephony has rapidly become the most popular method of voice communication in Nigeria. Growth has been so rapid that Nigeria has been rightly described in various fora as one of the fastest growing GSM markets in the world".

Indeed these developments have been truly explosive; according to statistic from Nigerian communication commission (NCC), compared with just about 450,000 working lines from NITEL in 2001 by August 2004, the GSM operator had recorded over seven million subscribers. By May 2005 Nigeria, with an estimated population of $128,771,988$, had more than nine million GSM subscribers, making the country one of the fastest growing GSM market in the world [10].

The GSM family of technologies provided the world with mobile communication since 1991. In over twenty years of development, GSM has been continually enhanced to provide platform that deliver an increasingly broad range of mobile services as demand grows. Where the industry started with plain voice calls, it now has a powerful platform capable of supporting mobile broadband and multimedia services. 
GSM is now used in over 219 countries and territories serving more than three billion people and providing travelers with access to mobile service wherever they go.

\section{GSM NETWORK ARCHITECTURE}

GSM Network consists of three main parts:

- Mobile Station (MS) carried by the subscriber

- Base Station Subsystem (BSS) controls radio link with mobile station

o Network \& Switching Subsystem (NSS) mobility management and switching of calls between mobile users, and between mobile and fixed network users.

\section{A. Mobile Station}

Consists of:

- Mobile Equipment (ME) such as hand portable and vehicle mounted unit

- Subscriber Identity Module (SIM), which contains the entire customer related information (identification, secret key for authentication, etc.)

\section{B. Base Station Subsystem}

Consists of:

- Base Transceiver Station (BTS) defines a cell and is responsible for radio link protocols with the Mobile Station

- Base Station Controller (BSC) controls multiple BTSs and manages radio channel setup, and handovers. The BSC is the connection between the Mobile Station and Mobile Switching Center.

1) Network and Switching Subsystems

Consists of:

- Mobile Switching Center (MSC) is the central component of the NSS. Operates all switching functions for the mobiles within its jurisdiction. Interface between mobile and other (including fixed) network. Its functions:

o Manages the location of mobiles

o Switches calls

o Manages Security features

o Controls handover between $\underline{\text { BSCs }}$

o Resource management

o Interworks with and manages network databases

o Collects call billing data and sends to billing system

o Collects traffic statistics for performance monitoring

- Network Databases - Home Location Register and Visitor Location Register together with MSC provides the call routing and roaming capabilities of GSM.

o Home Location Register (HLR) contains all the subscriber information for the purposes of call control, and location determination. There is logically one HLR per GSM network, although it may be implemented as a distributed database.

o Visitors Location Register (VLR) is only a temporary storage while the particular subscriber is located in the geographical area controlled by the

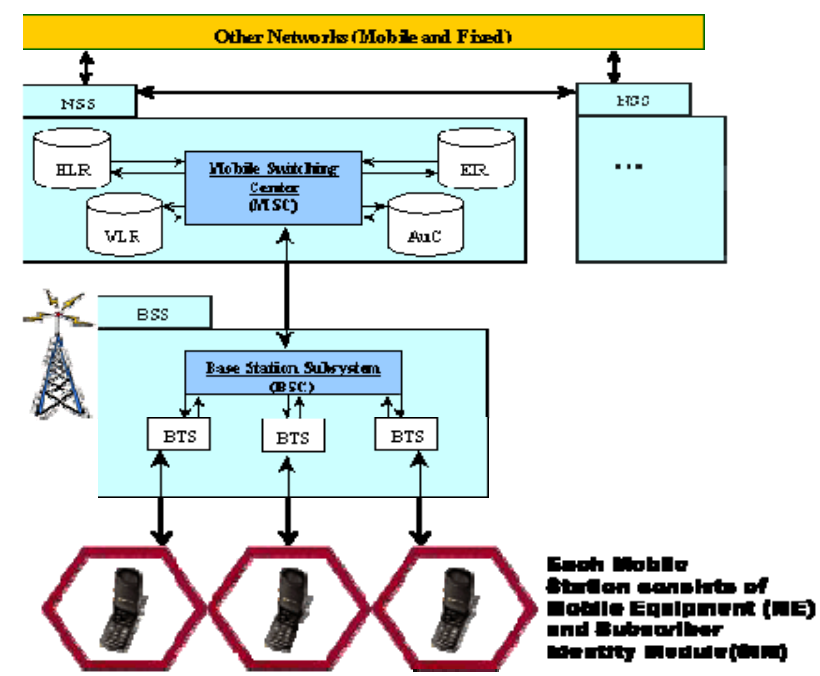

Figure 1. Layout of generic GSM network (Source: http://www.pulsewan.com/data101/gsm_basics.htm)

MSC/VLR. Contains only the necessary information provision of subscribed services.

o Authentication Center (AuC) is a protected database that stores the security information for each subscriber (a copy of the secret key stored in each SIM).

o Equipment Identity Register (EIR) is a list of all valid mobile equipment on the network [19].

\section{GSM OPERATORS IN NIGERIA}

At the moment, there are nine GSM operators in Nigeria: MTN, Zain, GloMobile, Mtel, Etisalat, Zoom, Starcomms, Visafone and Multilink.

\section{A. STARCOMMS}

Starcomms Nigeria PLC is a Telecommunication company with a strong operational base in Lagos and across the country. The growth of Telecoms in Nigeria, a West African country with the fastest recorded telecommunication growth in recent times has meant good business too for Starcomms.

Nigeria is a country booming economically due to the influx of investment as part of the fledging democratic environment as well as increasing revenues from crude oil which is equally increasing per capita income and earnings of the middle class. The decay in the national telecommunications network has given rise to privatization of the sector which has equally given room for other competing telecoms network to enter the market such as MTN, Globacom, Zain and others. Starcomms too is a growing company which has become one of the most popular CDMA networks in the country with deep roots in the south and north. Starcomms Nigeria has got its own strategy in penetration the market and her entry has won appeal by many due to lower prices for calls, a wider variety of services and the promotion of its brands. Starcomms also offers a high quality internet service and it comes in different packages:

- Starcomms CDMA browsing

- Starcomms Izap

- Starcomms Genie 
Starcomms is contributing to the growth of the Nigerian economy and has a large number of employees in its workforce [22].

\section{B. VISAFONE}

Voted The Best ICT Company and Best Telecom Brand in Nigeria for 2008, Visafone Communications Ltd (hereinafter to be referred to as Visafone or "the Company) was born out of the strategic acquisition of 3 CDMA mobile network operators that had been in operation for up to 8 years with 30,000 subscribers and coverage in different parts of Nigeria.

The company, which was incorporated in Nigeria on June 20, 2007 following the acquisition of Cellcom received its Unified Access Service Licence as a telecom operator from the Nigerian Communications Commission (NCC) on August 1, 2007 positioned it to offer mobile, fixed and any other telecommunications service to its subscribers.

Visafone, in the intervening yawn of time, amassed over 3 million subscribers after 16 months of operation and crossed the 1million subscriber mark in just 6 months from its launch in February 2008. Thus, recording an unprecedented industry milestone as the fastest growing mobile company in Nigeria since the earliest it took a Nigerian based GSM company to hit 1 million was 9 months.

Visafone's service excellence is anchored on the equation V=QC2 where V stands for Visafone; Q is for Quality of Service; and the Cs are for Clarity and Coverage. With its Unified Access Service Licence, $800 \mathrm{MHz}$ spectrum and strategic acquisitions, Visafone aims to become the pre-eminent telecom operator in Nigeria by offering seamless and efficient services that will ensure the best clarity and the widest coverage.

The company offers an exciting bouquet of superior telecommunications services that will encompass the very best of Voice, High Speed Data (3G), internet and other innovative Value Added Services to individual subscribers while also providing unequalled business solutions to both corporate entities as well as the Small \& Medium Scale Enterprises in Nigeria.

Visafone's strategic destination is to be among the top 3 telecoms operators in the country by 2012 [23].

\section{Multilinks}

Multi-Links Telecommunications Limited was incorporated in 1994 as a private limited liability company under the Laws of the Federal Republic of Nigeria. It was licensed by the Nigerian Communications Commission (NCC) to operate and provide telecommunications services deploying CDMA (Fixed Wireless) technology. It commenced operations on the 8th of December 1997 as the pioneer operator in the deregulated telecom industry in Nigeria.

In May 2006, the company was licensed by the NCC to provide and operate Unified Access Service in Nigeria. Its scope of operations was thereby expanded to include provision of Digital Mobile Services, Fixed Telephony Services, International Data Access Services and National Long Distance Services.

Shortly after, it was acquired by Telkom (Proprietary) International Limited now providing management services for the company. Multi-Links is now strategically positioned as an industry leader.

\section{Services}

The company's network has been expanded to cover the four geographical zones of Nigeria including the urban, semi- urban and rural arrears. Its subscriber base has grown remarkably to over $2.5 \mathrm{M}$ subscribers.

Its products being provided on a voice and data platforms include retail and wholesale services to both end users and operators/service providers.

The Company is now positioned to be the foremost ICT service provider and carriers' carrier in the Nigerian telecom industry [21].

\section{E. Zoom Mobile}

ZOOM mobile was incorporated on August 25, 1998, as Reliance Telecommunications Limited (Reltel Wireless), taking advantage of the deregulation of the sector by the then Federal Government of Nigeria.

The company obtained a National License subsequently to provide fixed wireless telephone Services in Nigeria.

Nortel Networks of USA deployed the first state-of-theart Code Division Multiple Access (CDMA) equipment operating on $1900 \mathrm{MHz}$ frequency. Full commercial operations commenced in Nigeria in November 2001.

With the expiration of exclusive mobility period enjoyed by the GSM operators, Zoom Mobile successfully applied for the Unified Access Service License, enabling it to provide full roaming services in all its areas of coverage.

The ZOOM mobile person is a skilled professional who is knowledgeable about his/her area of specialization. A consultant in his/her own right.

The ZOOM mobile person is dedicated to providing solutions to the challenges faced by his/her subscriber anytime, anyday and anywhere ensuring the subscriber uses our' products and services always with a pleasing experience [24].

\section{F. Etisalat}

Etisalat is the latest entrant in the GSM / Unified access scene in Nigeria. Etisalat is a Nigerian company formed by the partnership of Mubadala Development Company and Etisalat of the United Arab Emirates. Etisalat acquired the Unified Access License from the Federal Government in January 2007. The license includes a mobile license and spectrum in the GSM 1800 and $900 \mathrm{MHz}$ bands at a price of \$400million (Four Hundred Million U.S. Dollars) [25].

\section{G. Nigeria Mobile Telecommunications Ltd (M-Tel)}

Mobile Telecommunications Limited (MTel) (the mobile subsidiary of the national carrier, NITEL) was Nigeria's First Mobile Network, long before the advent of GSM [25].

\section{H. Glomobile}

Glomobile, the mobile arm of Globacom, Nigeria's Second National Operator (SNO). Glomobile always coming out with innovations and was the first to launch per second billing [25].

\section{MTN Nigeria}

MTN Nigeria is a member of the MTN group. MTN is acknowledged presently as the GSM market leader [25]. 


\section{J. Zain Nigeria / (former Celtel, former Vmobile)}

Formerly Econet Wireless Nigeria, (EWN) which is now Vee Networks of Nigeria (Vmobile) - and was acquired by Celtel in 2006, then acquired by Zain [25].

Nine years after the start of GSM era in Nigeria the focus has shifted from providing coverage to providing good service. The euphoria of owning a phone set is gradually giving way to complaints of dropped calls and network congestion. The operators are fast in realizing that they are in a high competitive environment where subscribers can make or break them. Dissatisfaction by subscribers gives rise to a high rate of subscribers chum and low revenue for the operator. The performance of the network has a direct impart the revenues [10].

The NCC and the national assembly are bringing pressure to the operators to set up the quality of services offered Nigerians and had even gone a step further to award contracts to private companies to conduct comparative analysis of the quality service offered by each of the operator. The NCC is further threatening to sanction any operator that fails to pay attention to quality.

\section{GSM SERVICES}

GSM Services are a standard collection of applications and features available to mobile phone subscribers all over the world. The GSM standards are defined by the 3GPP collaboration and implemented in hardware and software by equipment manufacturer and mobile phone operators.

The common standard makes it possible to use the same phones with different companies' services, or even roam into different countries. GSM is the world's most dominant mobile phone standard. The design of the service is moderately complex because it must be able to locate a moving phone anywhere in the world, and accommodate the relatively small battery capacity, limited input/output capabilities, and weak radio transmitters on mobile devices.

In order to gain access to GSM services, a user needs three things:

- a billing relationship with a mobile phone operator. This is usually either where services are paid for in advance of them being consumed (prepaid), or where bills are issued and settled after the service has been consumed (postpaid).

- A mobile phone which is GSM compliant and operates at the same frequency as the operator. Most phone companies sell phone from third party manufacturers.

- A SIM (Subscribers Identity Module) card which is activated by the operator once the billing relationship is established. After activation the card is then programmed with the subscribers MSISDN (Mobile Subscribers Integrated Services Digital Network Number) (The telephone number). Personal information such as contact numbers of friends and family can also be stored on the SIM by the subscribers [18].

After subscriber sign up, information about their identity (telephone number) and what services they allowed to access are stored in a "SIM record" in the home location Register (HLR). Once the SIM card is loaded into the phone and the phone is powered on; it will search for the nearest mobile phone mast, also called a base transceiver station or BTS. If a mast can be successfully contacted, then there is said to be coverage in the area. The key feature of a mobile phone is the ability to receive and make call in any area where coverage is available. These is generally called roaming from a costumer perspective, but also called visiting when describing underling technical process.

The major services provided through GSM are voice calls, data transmission, short massages services (SMS) and supplementary service such as call forwarding, barring of out going calls, barring incoming calls advice of change (AC), call hold, Call waiting, multi party service, calling line identification presentation/restriction, Closed User Groups (CUGs) and Explicit Call Transfer (ECT)[18].

\section{A. Voice Calls}

Once a mobile phone has successfully attached to a GSM network as subscribed in the previous section, calls may be made from the phone to any other phone on the global public switched telephone network. The user dial the telephone number presses the send or talk key, and the mobile phone sends a call setup request messages to the mobile phone mast (BTS). The call setup request messages is handled next by the mobile switching center, which check the subscribers record held in the visitor location register to see if the outgoing call is allowed. If so, the MSC then routes the call in the same way that a telephone exchange does in a fixed network. If the subscribers is on a pay as you go tariff (sometimes known as prepaid), then an additional check is made to see if the subscribers has enough credit to proceed. If not, the call is rejected. If the call is allowed to continue, then it is continually monitored and the appropriate amount is decremented from the subscribers account. When the credit reaches zero, the call is cut off by the network.

\section{B. Data Transmission}

The GSM standard also provides separate facilities for transmitting digital data. This allowed a mobile phone to act like any other computer in internet, sending and receiving data via the internet protocol. The mobile may also be connected to a desktop computer, laptop, or PDA, for use as a network interface.

\section{Short Message Services (SMS)}

A unique feature of GSM is the Short Message Service (SMS), which has achieved wide popularity as some have called the unexpected 'killer application' of GSM. SMS is a bi-directional service for sending short alphanumeric message in a store-and-forward process. SMS can be used both 'point-to-point as well as in cell broadcast mode. Supplementary services are provided on top of teleservices or bearer services, and include features such as, inter alia, call forwarding, call waiting, caller identification, three-way conversations, and call barring.

Short messages (more commonly known as text messages) has become the most used data application on mobile phones, with $74 \%$ of mobile phone users worldwide already as active user of SMS, or 2.4 billion people at the end of 2007. In many advanced countries, the users have shifted from considering the voice call being the most desired feature of a mobile phone, to considering SMS text massaging as the most desired feature.

SMS text messages may be sent by mobile phone users to other mobile users or external services that accept SMS. 
The messages are usually sent from mobile device via the short message service center using the MAP protocol. The SMSC is a central routing hubs for short messages. Many mobile services operator use their SMSCs gateways to external systems, including the Internet, incoming SMS news feeds, and other operators. The SMS standard is also used outside of the GSM.

\section{EXAMINATION MALPRACTICES IN NIGERIA EDUCATIONAL SECTOR}

Examination is defined as an organized assessment technique which presents individuals with a series of questions or tasks geared toward ascertaining the individual acquired skill and knowledge [12]. It is a method of testing the intelligence and knowledge of students on how well they comprehend a particular teaching. It is a formal means of testing student's knowledge or ability in a particular subject especially by means of written and oral questions or practical exercises [14].

Examination mal-practice on the other hand is defined as any irregular behaviour exhibited by candidates or anybody charged with the responsibility of conducting examination in or outside the examination hall, before, during or after such examination [20]. It is also defined as any action done or committed which makes it impossible to use an examination in determining the level of competence or applying knowledge [13]. In another definition examination malpractice is seen as an illegal or unethical behavior by somebody in the process of testing an examinee's ability or knowledge by means of question or any irregular behaviour exhibited by a candidate or anybody, during or after the examination which contravenes the rules and regulations governing the conduct of such examination. One could therefore see that academic cheating is an unethical method of using someone else position in a grading system, or any act or omission that is perpetuated to put a candidate at an unmerited and advantage over other students and/or to influence the examiner in giving unmerited grades [14].

\section{E-CHEATING}

E-cheating or electronic cheating can be defined as using information technology (IT) to aid in the process of cheating in a class. This includes the use of personal digital assistance $\left(\mathrm{PDA}_{\mathrm{S}}\right)$, camera or picture cell phones, twoway pagers, programmable calculators, computers, the Internet and so on to gain an unfair advantage.

Cheating in all educational institution in Nigeria has taken a new dimension with the advent of cell phones. Gone are the days of examination malpractice like stealing, impersonation, disorderliness, cheating, conspiracy and aiding, forgery of result slip, giraffe, laptop, machinery, microchips, smuggling answer scripts into examination halls and many others. Described as e-cheating, the cell phone technology is providing students with a smart way to beat the effort of examiners. Several services provided by GSM operators have brought examination malpractice in Nigeria schools to an alarming rate.

The modern student is bringing in-class cheating into the $21^{\text {st }}$ century with the likes of programmable calculators, personal data assistances, cellular phones and twoway pagers. Before now, known methods of exam malpractice by candidates and hired agents included leakage of exam question papers, bribery of supervisors and in- vigilators, impersonation, alteration of parade by officials, collusion among candidates, and now the recent one echeating.

The features of GSM phones that aid its use for examination malpractices are multi-purpose, accessibility, widespread, attainability, affordability and empowering.

- Multi-Purpose - Mobile phones originally served only one purpose: to send or receive voice communications. Today mobile phones have come equipped with customized software, Internet access, digital cameras, portable music players and GPS (Global Positioning System) functions.

- Accessible - About $50 \%$ of the world's population has access to a mobile phone, compared to $10 \%$ for personal computer.

- Widespread - Today there are nearly 4 billion mobile phone subscribers. (U.S. Agency for International Development)

- Attainable - More than $60 \%$ of the world's mobile phone users are in developing countries, with Africa having the highest mobile growth rate. Just one in Fifty Africans had mobile phones at the beginning of the $21^{\text {st }}$ century; today one in four does. (International Communication Union)

- Affordable - Mobile phones are cheaper, smaller and more portable than other digital devices. This enables a growing number of people to record a live event and immediately post it to the internet through a mobile network. (U. S. Agency for International Development)

- Empowering - People using mobile phone cameras now have extraordinary power to expose human rights abuses and promote democratic activities. For example, in 2007, video and still photos shot by individuals using mobile phones of monks and citizens marching for greater freedom in Burma spread throughout the world in hours. (U. S. Agency for International Development)

The following are the observed ways students use cell phones to cheat in examinations.

- Text messages containing answers to questions may be sent to students through a cell phone from outside the examination hall.

- Students use cell phone calculator in an examination where they have been instructed not to use calculator.

- Students use cell phone to browse for solution to any question in an examination.

- Students may type their notes as a text message or draft into their cell phones to copy in the examination hall.

\section{RECOMMENDATIONS}

The following are recommended to avert the problem of examination malpractices through cell phone in Nigeria.

1. Provision of a monitoring device to intercept signals from GSM phones and communications gadgets used in transmitting answers to candidates.

2. Enforcing the compliance of candidates not to come to the exam hall with cell phones with strict penalty for disobedience. 
3. Turning off all operators' networks to disallow communication within the period of any national examination days.

4. Parents / Teachers need to educate their children / students that $\mathrm{A}$ is not an A unless it is earned; cheating should bring them no joy.

5. Religious bodies should be allowed to come in to our schools and reveal the mind of God as regards cheating to all students.

6. Students should be made to realize that it is an abuse of usage to use cell phone to cheat in the examination and it is punishable under the law.

\section{REFERENCES}

[1] Adeshina Sunday, Deborah Ogidigbo and Rosemary Bassey (April 16, 2010), The Plague of Examination Malpractice (Unpublished). Available at http://www.weekly.dailytrust.com/index.php?

[2] Alqueen Felix, Should Children Have Cell Phones at School? Available at www.helium.com/.../92065

[3] Andrey Selian, 3G Mobile Licensing Policy: From GSM to IMT2000-A Comparative Analysis. Available at http://www.itu.int/3g.

[4] Beth Lynne (March 11, 2007), Fair Cell PhoneUse in Schools, Pros and Cons of Cell Phones in School. Available at www.suite101.com/content/fair-cell-phone-use in schools-a-15906

[5] Bob Smithe (September 05, 2008), The Disadvantages of Letting Students Use Their Cell Phones at School. Available at www.associatedcontent.com/

[6] Carolyn N. Kinder, The Physics of Cell Phones. Available at http://www.yale.edu/ynhti/curriculum/units/2003/4/03.04.07.x.htm l.

[7] Darwin L. K. and Carl J. C. (2007), e-CHEATING: Are Students misusing it? Issues in Information Systems Volume viii, No 1.

[8] Fiona Johnson (August 18, 2006), Cell Phones May Be The Cause of Increased Cheating Among Children in School. Available at www.associatedcontent.com/

[9] Ime Ola and Gabriel Dike (May 15, 2007), e-cheating... JAMB faces new trend in exam fraud, The Sun publishing.
[10] Ireti Ajala (Nov. 26, 2005), GIS and GSM Network Quality Monitoring: A Nigeria Case Study, Directions Magazine.

[11] Katherine Shaw (July 04, 2005), More: Cell Phones Internet Phones Music Phones Camera Phones Cell Phone Ban.

[12] Okoye N. M. (1986). Challenges of Nigeria School Certificate Examination. Ibadan: Evans.

[13] Onyechere I. (2004). Cheating: A world-wide problem In 'Comes in At Least 33 Way'. All Africa.com. March 4, 2004.

[14] Stephen O. Y. B. (May 12, 2008), Examination Malpractice in Nigerian Educational Sector: A Spiritual Solution.

[15] Taiwo Odunlami, Candidate Cheats With GSM Phone During Exams. Available at www.naijarules.com/

[16] Exam Malpractices Is Common With Students, NECO Registrar, Available at http://www.enownow.com.

[17] “Cell Phones at Schools: Should They Be Allowed?” Available at life.familyeducation.com/cellular-telephones/school/51264.htm.

[18] GSM Services, Wikipedia, the free encyclopedia.

[19] What is GSM? Available at www.pulsewan.com/data101/gsm_ba sics.htm.

[20] West African Examination Council Forum (2003). Students Tricks in Examination. Lagos, WAEC.

[21] Welcome to Multilinks. Available at www.multilinks.com/ multilinks1/index.asp?multilinks. September 10, 2010.

[22] Starcomms Nigeria. Available at www.starcomms.com/, September 10, 2010.

[23] Visafone Communication. Available at www.visafone.com.ng/. September 10, 2010.

[24] ZOOM mobile NIGERIA. Available at www.zoomnigeria.com/. September 10, 2010.

[25] GSM Operators in Nigeria. Available at www.jidaw.com/tele com/gsm.html. September 10, 2010.

\section{AUTHORS}

Olufemi Sunday Adeoye is with the Department of Computer Science, University of Uyo, Nigeria, olaphem2000@yahoo.com

Submitted September $26^{\text {th }}, 2010$. Published as resubmitted by the author November 22th, 2010. 